\title{
Glutathione Production Using Magnetic Fields Generated by Magnets
}

\author{
Lucielen Oliveira dos Santos ${ }^{*}$, Tatiane Araujo Gonzales ${ }^{2}$, Beatriz Torsani Úbeda ${ }^{2}$ and \\ Ranulfo Monte Alegre ${ }^{2}$ \\ ${ }^{I}$ Departamento de Tecnologia de Alimentos; Instituto de Tecnologia; Universidade Federal Rural do Rio de \\ Janeiro; C. P.: 74573; 23890-971; Seropédica - RJ - Brasil. ${ }^{2}$ Departamento de Engenharia de Alimentos; \\ Faculdade de Engenharia de Alimentos; Universidade Estadual de Campinas; C. P.: 6121; 13083-862; Campinas - \\ SP - Brasil
}

\begin{abstract}
The objective of this work was to study the production of GSH by Saccharomyces cerevisiae ATCC 7754 in a fermentor $(5 \mathrm{~L})$ using a cell recycle system with magnets. The fermentation conditions were $20^{\circ} \mathrm{C}, 500 \mathrm{rpm}, 5 \%(\mathrm{v} / \mathrm{v})$ of inoculum, $\mathrm{pH}_{\text {initial }} 5,1.1 \mathrm{vvm}$ aeration and total fermentation time of $72 \mathrm{~h}$. The time of application of MF ranged from 24, 48 or $72 \mathrm{~h}$. In comparison to the control experiment, the best results were obtained with $72 \mathrm{~h}$ of application of MF. The cell concentration reached $19.5 \mathrm{~g} / \mathrm{L}$ and $\mathrm{GSH}$ concentration was $271.9 \mathrm{mg} / \mathrm{L}$ that corresponded to an increase of 2.63 and $32.1 \%$ compared to the control experiment, respectively.
\end{abstract}

Key words: glutathione, magnetic field, Saccharomyces cerevisiae, batch fermentation

\section{INTRODUCTION}

Glutathione, (GSH) is a biologically active tripeptide consisting of L-glutamate, L-cysteine and glycine (Zhang et al. 2007). The biosynthesis of GSH in humans occurs in virtually all cell types, with the liver being the major producer and exporter (Wu et al. 2004). One of its most important functions is as an antioxidant against the toxic effects of oxygen and other oxidative compounds (Fan et al. 2004). Glutathione deficiency contributes to oxidative stress, which plays a key role in aging and the pathogenesis of many diseases (including kwashiorkor, seizure, Alzheimer's disease, Parkinson's disease, liver disease, cystic fibrosis, sickle cell anemia, HIV, AIDS, cancer, heart attack, stroke and diabetes) (Wu et al. 2004). Zhang et al. (2007) reported that GSH was widely used as a pharmaceutical compound and has the potential to be used in food additives and in the cosmetic industries.

Some yeast strains have the ability to accumulate glutathione in the cells. Yeast fermentation is an efficient approach to commercially produce glutathione (Wen et al. 2005). Glutathione can be produced by direct fermentative methods using sugar as a starting material. Saccharomyces cerevisiae and Candida utilis are currently used to produce glutathione on an industrial scale ( $\mathrm{Li}$ et al. 2004). S. cerevisiae is widely used in ethanol production. Many studies have been conducted to assess the culture media, types of fermenters and immobilization of yeasts (Alegre et al. 2003).

Being an intracellular product in yeast, GSH production can be enhanced in two ways: increasing the cell biomass largely, or improving GSH content in yeast greatly. It is comparatively easier to increase the cell mass by fermentation

*Author for correspondence: santoslucielen@gmail.com 
technology than to elevate the intracellular GSH content. Improving the intracellular GSH content in yeast is more attractive because it would not only increase GSH production remarkably but also be helpful for the down processing (Wen et al. 2004).

Stimulation or inhibition of cellular processes by the magnetic fields (MF) are of considerable interest in cell biology and biotechnology for not only establishing the basic mechanisms of this interaction but also its potential practical applications (Lei and Berg 1998). Depending on the shape and values of characteristic parameters (intensity, frequency, length or time constant in the case of impulses), different effects appears (Fologea et al. 1998). The inhibition or stimulation of the vital activity of microorganisms can be obtained by selecting the appropriate parameters of the MF (Pichko and Povalyaeva 1996).

The mechanism of the stimulation is not yet known. It might be connected with some changes at the membrane level, because many transmembrane flows are enhanced (Fologea et al. 1998). Under laboratory conditions, a variety of biological responses can be induced by exposure to MF. Representative examples include altered rates of DNA, RNA and protein synthesis, effects on cell growth, increased levels of enzymes associated with cell proliferation and changes in cell surface properties (Binninger and Ungvichian 1997). The fields affect the direction of migration and alter the growth and reproduction of microorganisms, causing a change in the rate of cell growth (Zapata et al. 2002; Zapata et al. 2005).

The objective of this study was to determine the influence of MF generated by magnets in GSH concentration, produced by $S$. cerevisiae ATCC 7754.

\section{MATERIALS AND METHODS}

\section{Microorganism and medium}

The S. cerevisiae ATCC 7754 was obtained from the Tropical Culture Collection of the "Fundação André Tosello" (Campinas-SP, Brazil). The strain used was maintained on YM agar (yeast extract malt extract). The medium for GSH production contained $(\mathrm{g} / \mathrm{L})$ : glucose $(54)$, yeast extract (50) and magnesium sulphate (12). The medium was sterilized by autoclaving at $121^{\circ} \mathrm{C}$ for $20 \mathrm{~min}$, except to glucose that was sterilized separately.

\section{Inoculum and culture conditions}

The slants were transferred into Erlenmeyer flasks and during $24 \mathrm{~h}$ the yeast grew on YM broth at $30^{\circ} \mathrm{C}$ and $150 \mathrm{rpm}$. The batch fermentation was operated in a 5-L fermentor (New-BrunswickBioflo III), equipped with sensors measuring temperature and $\mathrm{pH}$. The fermentor was adapted to a system of recycling of cell suspension through a magnetizer with magnets as shown in Fig. 1. The working volume was $3.5 \mathrm{~L}$. The $\mathrm{pH}_{\text {initial}}$, temperature, aeration, agitation, fermentation time and inoculum concentration were $5,20^{\circ} \mathrm{C}, 1.1$ $\mathrm{vvm}, 500 \mathrm{rpm}, 72 \mathrm{~h}$ and $5 \%(\mathrm{v} / \mathrm{v})$, respectively. The air was supplied by the compressor and filtered by passing through a filter. During fermentation, amino acids were added after $6 \mathrm{~h}: 2$ $\mathrm{mM}$ cysteine and after $28 \mathrm{~h}: 3.35 \mathrm{mM}$ cysteine, 10 $\mathrm{mM}$ glutamic acid and $18 \mathrm{mM}$ glycine and samples were taken at regular intervals of time.

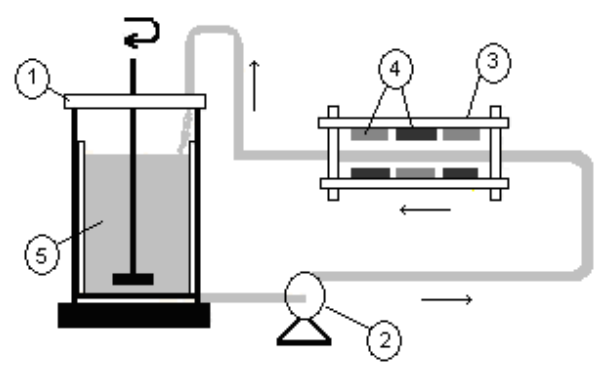

Legend:
1- Fermentor Bioflo III
2- Pump to cell suspension recirculation

Figure 1 - Schematic of the magnetic treatment of cell suspension. 
A control experiment (CE) was made without the application of MF and with cell recycling, under the same conditions of fermentation with the application of MF. After that three fermentations were made by varying the time of application of $\mathrm{CM}$ at 24,48 or $72 \mathrm{~h}$. The magnets were placed at a distance of $5 \mathrm{~mm}$ of tube recycle and MF was 20 mT (200 Gauss). The cell recycling was done by using a peristaltic pump (Anko 913 MITY Flex, USA) and the speed of cell recycling was $5.2 \mathrm{~cm} / \mathrm{s}$.

\section{Analytical Determinations}

Biomass concentration was determined using $\mathrm{HACH}$ spectrophotometer (Mod. DR/4000U) at $600 \mathrm{~nm}$. A standard curve correlating the absorbance and dry mass was made to calculate. The supernatant obtained after centrifugation of the sample was used as a blank to eliminate the interference of the medium. The determination of $\mathrm{pH}$ of each sample was done by $\mathrm{pH}$ meter
(Digimed, Mod. DM $20 \mu \mathrm{P}$, Santo Amaro, Brazil). The concentration of glucose was determined using an enzymatic kit and colorimetrically (BioDiagnostics). The concentration of GSH was determined using the method of Owens and Belcher (1965).

\section{RESULTS}

Fig. 2 shows the results obtained during the control experiment (without application of MF). The $\mathrm{pH}_{\text {final }}$ was 6.5 and the glucose was consumed within $24 \mathrm{~h}$ of fermentation. The maximum cell concentration and GSH were $19.0 \mathrm{~g} / \mathrm{L}(72 \mathrm{~h})$ and $205.8 \mathrm{mg} / \mathrm{L}(68 \mathrm{~h})$, respectively. These values were used to compare with experiments made with the application of MF. In the second experiment, the application of MF occurred from 0 to $24 \mathrm{~h}$ of fermentation. The results are shown in Fig. 3.

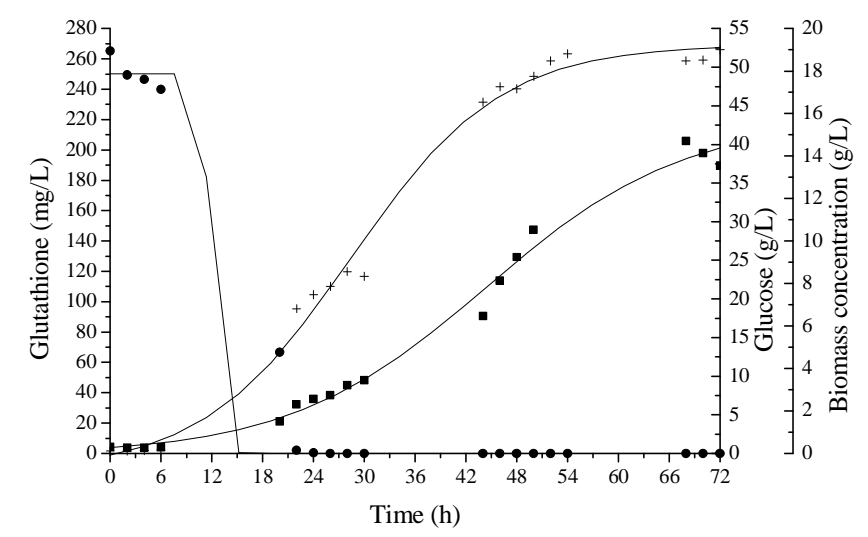

Figure 2 - Control experiment (without MF): $(+)$ biomass concentration $(\mathrm{g} / \mathrm{L}),(\bullet)$ glucose $(\mathrm{g} / \mathrm{L})$ and (ם) GSH (mg/L).

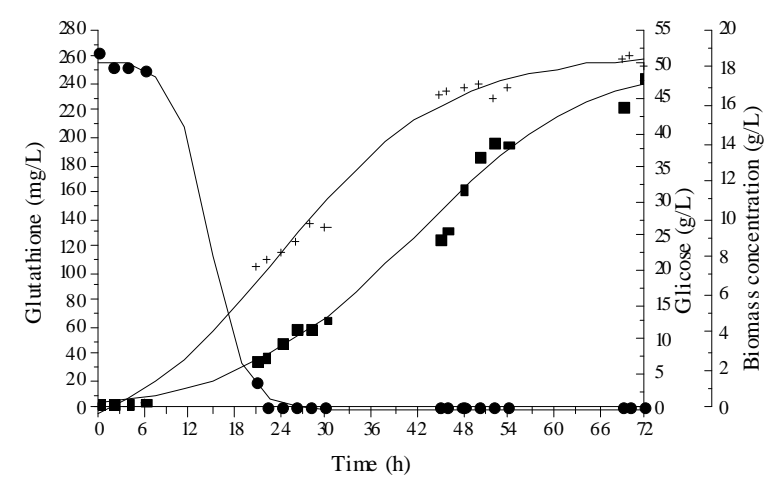

Figure 3 - Experiment with application of MF for 24 h: $(+)$ biomass concentration (g/L), $(\bullet)$ glucose $(\mathrm{g} / \mathrm{L})$ and $(\mathbf{\square}) \mathrm{GSH}(\mathrm{mg} / \mathrm{L})$. 
Evidently, glucose was completely consumed by $22 \mathrm{~h}$ and the $\mathrm{pH}_{\text {final }}$ was 5.44. The maximum biomass concentration was $18.6 \mathrm{~g} / \mathrm{L}$ after $70 \mathrm{~h}$ and concentration of GSH was $245.7 \mathrm{mg} / \mathrm{L}$ at $72 \mathrm{~h}$. In the experiment with application of MF from 0 to
$48 \mathrm{~h}$, the $\mathrm{pH}_{\text {final }}$ was 5.59 and the glucose was consumed by $21 \mathrm{~h}$. The highest biomass concentration was achieved between $69-70 \mathrm{~h}(18.8$ $\mathrm{g} / \mathrm{L}$ ) and $\mathrm{GSH}$ was $259.9 \mathrm{~g} / \mathrm{L}$ after $72 \mathrm{~h}$ of fermentation (Fig. 4).

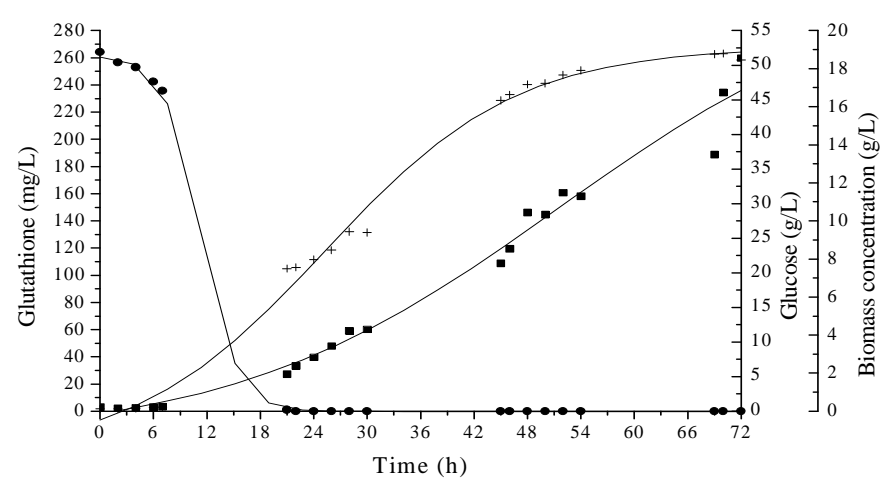

Figure 4 - Experiment with application of MF for $48 \mathrm{~h}$ : (+) biomass concentration $(\mathrm{g} / \mathrm{L}),(\bullet)$ glucose $(\mathrm{g} / \mathrm{L})$ and $(\square) \mathrm{GSH}(\mathrm{mg} / \mathrm{L})$.

Figure 5 shows the results with application of $72 \mathrm{~h}$ of MF. The glucose was consumed until $26 \mathrm{~h}$ of fermentation and $\mathrm{pH}_{\text {final }}$ was 6.02. The biomass concentration was $19.5 \mathrm{~g} / \mathrm{L}$ and the highest concentration of GSH was $271.9 \mathrm{mg} / \mathrm{L}$ after $70 \mathrm{~h}$ of fermentation. Table 1 shows the percentage of difference in biomass concentration (PDB) and the percentage of difference in GSH concentration
(PDG) in relation to the control experiment. The highest values of biomass concentration and GSH for each test were used to compare the results.

With the application of magnetic fields for longer times, best results were achieved. In relation to the biomass concentration with only $72 \mathrm{~h}$ of application of MF, a small stimulatory effect in relation to the control experiment was observed.



Figure 5 - Experiment with application of MF for $72 \mathrm{~h}$ : (+) biomass concentration $(\mathrm{g} / \mathrm{L}),(\bullet)$ glucose $(\mathrm{g} / \mathrm{L})$ and $(\mathbf{\square}) \mathrm{GSH}(\mathrm{mg} / \mathrm{L})$.

Table 1 - Results of percentage of difference in biomass concentration (PDB) and the percentage of difference in GSH concentration (PDG).

\begin{tabular}{lcccc}
\multicolumn{1}{c}{ Experiment } & Biomass concentration $(\mathbf{g} / \mathbf{L})$ & PDB $(\boldsymbol{\%}) *$ & GSH $(\mathbf{m g} / \mathbf{L})$ & PDG $(\boldsymbol{\%}) *$ \\
\hline Control & 19.0 & - & 205.8 & - \\
24 h of MF & 18.6 & -2.11 & 245.7 & +19.4 \\
48 h of MF & 18.8 & -1.05 & 259.9 & +26.3 \\
$72 \mathrm{~h}$ of MF & 19.5 & +2.63 & 271.9 & +32.1 \\
\hline
\end{tabular}

* (+) stimulatory effect and (-) inhibitory effect. 


\section{DISCUSSION}

Results showed that the time of application of magnetic fields influenced the concentrations of biomass and GSH produced by the yeast. In the experiments with 24 or $48 \mathrm{~h}$ of application of MF, the values of PDC were small and could be due to errors inherent in the process; the application of MF had no effect for the biomass concentration. However, for GSH concentration in all the experiments, stimulatory effects, ranging from 19.4 to $32.1 \%$ were observed, which was the highest value was achieved with the implementation of the MF throughout the fermentation $(72 \mathrm{~h})$.

The advantage of the application of MF with the use of magnets is the cell recycling, because this system makes it easy to scale-up. According to Alvarez et al. (2006), several MF generator devices have been developed to study the biological effects of MF on biological materials. Although, the application on industrial scale is very difficult, due to the MF devices generator be designed to cover all or most part of the fermentor and certainly, this is technically and economically unviable for application on larger volumes. The apparatus used in this study, i.e., the medium of fermentation containing the cells was recycled through stainless steel tube insert between the magnet prisms, which could be easily implemented on industrial scale.

Regarding the biomass concentration $S$. cerevisiae, some authors have observed stimulatory effects using others MF and exposure times. Picho and Povalyaeva (1996) achieved 12\% increase in biomass concentration of $100 \mathrm{mT}$ for $0.67 \mathrm{~h}$, which was also by Mehedintu and Berg (1997) $25 \%$ (0.2 $\mathrm{mT}$ and $10 \mathrm{~h}$ ), Motta et al. (2001) $1.84 \%$ (220 mT and $24 \mathrm{~h}$ ), Zapata et al. (2005) $14.4 \%$ using $0.002 \mathrm{mT}$ for $30 \mathrm{~s}$.

Muniz et al. (2007) studied the growth of $S$. cerevisiae DAUFPE-1012 when exposed to MF $(220 \mathrm{mT})$. The biomass growth rate increased 2.5 times in relation to un-exposed culture.

In the literature, only one work has been reported the application of MF for the production of GSH by fermentation. Santos et al. (2010) study the effect of MF on GSH production by $S$. cerevisiae ATCC 7754. In all experiments, the amount of biomass produced was higher than in control experiments (CE). The highest GSH $(340.0 \mathrm{mg} / \mathrm{L})$ and biomass $(16.3 \mathrm{~g} / \mathrm{L})$ were obtained using MF induction and these results were $39.0 \%$ and $19.6 \%$ higher than in the CE, respectively.

In this work an increase of $32 \%$ was a considerable a good value, because it was an intracellular product.

\section{CONCLUSIONS}

The results of this work were important and showed that the MF influenced the cell growth of $S$. cerevisiae. With the implementation of MF using magnets, stimulating effects were observed for the production of GSH and biomass. The highest cell concentrations (19.5 g/L) and GSH $(271.9 \mathrm{mg} / \mathrm{L})$ were achieved with the application of MF during the $72 \mathrm{~h}$ of fermentation, representing an increase $2.63 \%$ and $32.1 \%$ in relation to control experiment.

\section{REFERENCES}

Alegre RM, Rigo M, Joekes I. Ethanol fermentation of a diluted molasses medium by Saccharomyces cerevisiae immobilized on chrysotile. Braz Arch Biol Technol. 2003; 46: 751-757.

Alvarez DC, Pérez VH, Justo OR, Alegre RM. Effect of the extremely low frequency magnetic field on nisin production by Lactococcus lactis subsp. lactis using cheese whey permeate. Process Biochem. 2006; 41: 1967-1973.

Binninger DM, Ungvichian V. Effects of $60 \mathrm{~Hz}$ AC magnetic fields on gene expression following exposure over multiple cell generations using Saccharomyces cerevisiae. Bioelectrochem. Bioenerg. 1997; 43: 83-89.

Fan X, He X, Guo X, Qu N, Wang C, Zhang B. Increasing glutathione formation by functional expression of the $\gamma$-glutamylcysteine synthetase gene in Saccharomyces cerevisiae. Biotechnol Lett. 2004; 26: 415-417.

Fologea D, Vassu-Dimov T, Stoica I, Csutak O, Radu M. Increase of Saccharomyces cerevisiae plating efficiency after treatment with bipolar electric pulses. Bioelectrochem Bioenerg, 1998; 46: 285-287.

Lei C, Berg H. Electromagnetic window effects on proliferation rate of Corynebacterium glutamicum. Bioelectrochem Bioenerg. 1998; 45: 261-265.

Li Y, Wei G, Chen J. Glutathione: a review on biotechnological production. Appl Microbiol Biotechnol. 2004; 66, 233-242. 
Mehedintu M, Berg H. Proliferation response of yeast Saccharomyces cerevisiae on electromagnetic field parameters. Bioelectrochem Bioenerg. 1997; 43: 6770.

Motta MA, Montenegro EJN, Stamford TLM, Silva AR, Silva FR. Changes in Saccharomyces cerevisiae development induced by magnetic fields. Biotechnol Prog. 2001; 17: 970-973.

Muniz JB, Marcelino M, Motta M, Schuler A, Motta MA. Influence of static magnetic fields on $S$. cerevisiae biomass growth. Braz Arch Biol Technol. 2007; 50: 515-520.

Owens CWI, Belcher RV. A colorimetric micro-method for the determination of glutathione. Biochem $J$. 1965; 94: 705-711.

Pichko VB, Povalyaeva IV. Electromagnetic stimulation of microorganism productivity: possible mechanisms. Appl Biochem Microbiol. 1996; 32: 425-428.

Santos LO, Alegre RM, Garcia-Diego C, Cuellar J. Effects of magnetic fields on biomass and glutathione production by the yeast Saccharomyces cerevisiae. Process Biochem. 2010; 45: 1362-1367.

Wen S, Zhang T, Tan T. Utilization of amino acids to enhance glutathione production in Saccharomyces cerevisiae. Enzyme Microb Technol. 2004; 35: 501507.
Wen S, Zhang T, Tan T. Optimization of the amino acid composition in glutathione fermentation. Process Biochem. 2005; 40: 3474-3479.

Wu G, Fang Y, Yang S, Lupton JR, Turner ND. Glutathione metabolism and its implications for health. J Nutr. 2004; 134: 489-492.

Zapata JE, Hoyos M, Moreno G. Acción de un campo magnético sobre un cultivo aireado de Saccharomyces cerevisiae. Interciencia. 2005; 30: 409- 413

Zapata JE, Moreno G, Márquez EJ. Efectos de los campos magnéticos sobre el crecimiento de Saccharomyces cerevisiae. Interciencia. 2002; 27: 544- 550.

Zhang T, Wen S, Tan T. Optimization of the medium for glutathione production in Saccharomyces cerevisiae. Process Biochem. 2007; 42: 454-458.

Received: March 09, 2012; Revised: May 03, 2012; Accepted: August 20, 2012. 